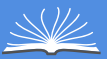

Global Journals Inc.

की

\title{
Conflict and Reconciliation Beween Orient and Occident in A Passage to India and A Passage to England
}

By Mahmoda Khaton Siddika International Islamic University Chittagong

Abstract- E. M. Forster's A Passage to India nourishes the facet of superiority and inferiority, self and other between occident and orient revealed in Orientalism. Through the character analysis and the development of the plot, the writer shows the conflicts of these senses. The novel narrates the colonial exercise-the English's rule in India and the relationship between the Indians and the English. The perceived idea, misconception, and colonial politics prevail in the two races. The characters from the English and the Indians find the oriental concept a barrier in their integration for giving pre-eminence of everything occidental and representing the oriental as an inferior other. On the other hand, though Chaudhuri in his travelogue, A Passage to England rounds with a preconceived idea formulated by the west, he feels doubt to meet the west. But he feels home with the west after meeting them. The writer, through his experience, tries to find out the explanation of the west's negative view on the East. The article tries to explore whether a proper reconciliation or harmony is possible in the conflict of orient and occident following thesisantithesis-synthesis through the comparative analysis of these books.

GJHSS-A Classification: FOR Code: 199999

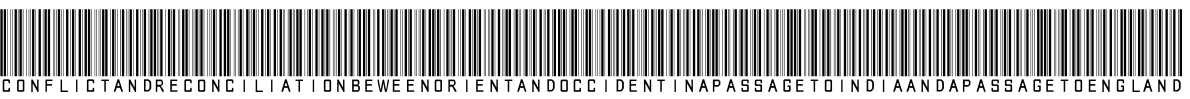

Strictly as per the compliance and regulations of:

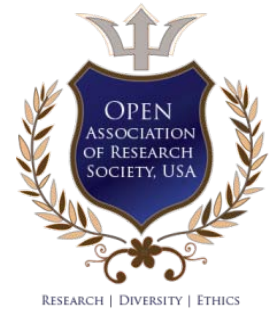

(C) 2021. Mahmoda Khaton Siddika. This is a research/review paper, distributed under the terms of the Creative Commons Attribution-Noncommercial 3.0 Unported License http://creativecommons.org/licenses/by-nc/3.0/), permitting all non-commercial use, distribution, and reproduction in any medium, provided the original work is properly cited. 


\title{
Conflict and Reconciliation Beween Orient and Occident in A Passage to India and A Passage to England
}

\author{
Mahmoda Khaton Siddika
}

Abstract- E. M. Forster's A Passage to India nourishes the facet of superiority and inferiority, self and other between occident and orient revealed in Orientalism. Through the character analysis and the development of the plot, the writer shows the conflicts of these senses. The novel narrates the colonial exercise-the English's rule in India and the relationship between the Indians and the English. The perceived idea, misconception, and colonial politics prevail in the two races. The characters from the English and the Indians find the oriental concept a barrier in their integration for giving preeminence of everything occidental and representing the oriental as an inferior other. On the other hand, though Chaudhuri in his travelogue, $A$ Passage to Englandrounds with a preconceived idea formulated by the west, he feels doubt to meet the west. But he feels home with the west after meeting them. The writer, through his experience, tries to find out the explanation of the west's negative view on the East. The article tries to explore whether a proper reconciliation or harmony is possible in the conflict of orient and occident following thesisantithesis-synthesis through the comparative analysis of these books.

\section{INTRODUCTION}

W ithin the framework of their preconceived and prejudiced idea on the orient, the western people correlate the real orient. Thus, they always try to control the orient as the man has treated the female body as the second sex in feminism. This sense is evident in A Passage to India as Anglo- Indians act following the western view regarding the East in Orientalism. The novel depicts the relation of orient or the East as other and occident or the West as self by showing the superiority of the occident over the orient. Nayar (2010) unearths that in the 18th and 19th centuries "Europe and the Orient were discursively represented in literature and history as binary opposites. Europe was all that the Orient was not: developed, Christian, civilized. Europe saw the Orient as different and treated this difference as negative" (161). A Passage to India deals with occident as superior, self, and orient as inferior other revealed in orientalism. So, the article tries to explore all kinds of conflicts in the novel regarding orient and occident as placing occident's view and attitude as thesis and orient's outlook and perspective as an antithesis to attain the

Author: Assistant Professor of English. Center for University Requirement Courses, International Islamic University Chittagong, Bangladesh.e-mail: nazu_eng@yahoo.com argument. But, A Passage to England deals with the East as Indian and the West as the English, which probes into an explanation of the conflicts for differences of the East and the West. As a writer, he was fascinated with British culture. But as an Indian, he ignores the idea of a colonized society. He denies the definition of the orient from the occident's point of view. The colonized is no more the effeminate alien person and is not a subject for distortion by the colonizer. However, his attitude toward its people is neither inflated nor deflated. So, the article aims at revealing the conflicts between them and sorts out reconciliation through the process of thesis-antithesis-synthesis.

\section{il. Orientalism}

Within the framework of their preconceived and prejudiced idea on the orient shown in orientalism, the western people correlate with the real orient. Thus, they always try to control the orient. This sense is evident in A Passage to India. In this novel, Anglo-Indians act following the western view regarding the East in Orientalism. Indians like the East are interpreted and run by the Anglo-Indians without holding their views. Indians are in a dilemma to keep their perspective and the way of life. They always busy with making themselves a positive entity to the English, removing the scar of negative existence. The English sometimes break the center of views regarding Indians, but they afterward come to their actual center to recognize the Indians. Anglo-Indians always try to control and show superiority over Indians. In the same way, Chaudhuri in his travelogue, views Indians and the English through his perceived sense of English and western culture from reading books. Dependent variables in the article, orient and occident, are pointed for analyzing independent variables- conflict and reconciliation based on this theory. Thus, the article explores the nature of orient and occident conflict and explores reconciliation in this conflict.

\section{ili. Occident's View and Attitude as Thesis in A PASSAGE TO INDIA}

Forster's A Passage to India presents a culturally conflicting journey of both the English colonizers and the Indian colonized in British occupied 
Indian city, Chandrapore, in the 20th century. The writer, as an English holding his view about orient as unfavorable other, starts his description of Chandrapore and the river Ganges in this novel. In the very next moment, the writer presents by collecting information that the inland of this place offers a different outlook with increasing knowledge that "it is a tropical pleasance, washed by a noble river" (31). The writer depicts the Marabar hill with scenic beauty "containing the extraordinary caves" (33). Similarly, Adela Quested, an English woman who has visited during British Raj in India, like any other western, thinks of Indian within the perceived idea of the orient. Her knowledge about India out of her imagination from the existing expertise inspires her to observe actual India. She is disappointed at first for "the dullness of their new life" (46) in India for her negative idea about India. Adela applies her prejudiced view on Aziz for thinking of having several wives. "Mohammedans always insist on their full four" (163), learned from Mrs. Turton. During the journey, Adela has planned to tolerate Indian life. She thinks some Indians are the culprit. Miss Quested feels hesitation in expressing everything to Dr. Aziz as she is Anglo-Indian and he is Indian. Within the western structure, "Have you one wife or more than one?" (164)is the common question for Muslims. As Fielding out of his preconceived idea calls Dr. Aziz a little rogue, actually "licentious oriental imagination was at work" (270) and "East and West. Most misleading" (271).

As Said views on superior West and inferior East, says Barry (2006), that "Said identifies a European culture of a tradition of 'Orientalism,' which is a particular and long-standing way of identifying the East as 'other' and inferior to the West" (193). Bertens (2001) also remarks that "West and East form a binary opposition in which the two poles define each other, the inferiority that orientalism attributes to the East simultaneously serves to construct the west's superiority". In the same way, Anglo-Indians treat Indians as inferior others by holding their superiority. The novel reveals a useful colonial device to science, logic, and fact. For instance, this is visible in McBryde's thoughts:

Oriental Pathology, his favourite theme, lay all around him, and he could not resist it. Taking off his spectacles, as was his habit before enunciating a general truth, he looked into them sadly ... not a matter for bitterness this, not a matter for abuse, but just a fact which any scientific observer will confirm. (222)

The colonialists feel that there is no need to justify to the Indians the moral superiority of the British: it remains a fact for them. For example: "He [McBryde] made no moral or emotional appeal, and it was only by degrees that the studied negligence of his manner made itself felt, and lashed part of the audience to fury" (221). There is skepticism in the novel towards logic and fact. These are used for colonial purposes, that is, to suggest the inferiority of the Indian.
The British Raj is in an attitude of a controller and an administrator. They are not willing to maintain a personal relationship with Indians which they regard this kind of relation as nasty because "when an Indian goes bad, he goes not only very bad, but very queer" (177) and their relationship "always ends in some indignity" (193). Though Fielding knows the result of going against his race and he can be called "ANTI-British, seditious" (183), he knows that "at a crisis, the English are really unequalled" (183).

Anglo- Indians holding the western interpretation about the East shape their colonial administrative exercise and politics. They treat Indians as their subordinates and weak to prove the justification of their staying in India. Ronny is anxious for this year at the eve of Chandrapore Mohurram though he dislikes this day. It is his way to prove the importance of the British in India, and without them, there will only be bloodshed here. Goodman (2004) exposes that AngloIndians consider Indians as colonized being irrational, overemotional, and disorderly and incoherent, as like Dr. Aziz in the novel.

As a master's attitude to his subordinate, Major Callendar has denied young men three or two days leave to Calcutta because he thinks that "his subordinates were made of ice" (115). The English exercise post-impressionism in India that is a kind of privilege treated as a right for the ruling race. The English treat the Indians officially. Ronny as a bureaucrat does not tolerate a scene of an English girl's "smoking with two Indians" (94) in India, but the view is acceptable in England. He is determined not to allow Adela "messing about with Indians any more" (98), but Adela only can go to Marabar Caves with the British company. The Indian's interaction with Adela makes him annoyed because he does not let it happen. He predicts a muddle would happen over caves. Ronny always isolates himself as a British administrator. He never neglects an inch to hamper this administration since he does not take service under the Native States to avoid their influence over them "at the expense of the general prestige" (107). Lowe (1991) says that "among thirty essays by Indian scholars, only two (those by Chaudhuri and Naik) are overtly critical of British representations of Indians in Forster's novel as a symptom of the British imperial tradition ruling, and misunderstanding, the Indians".

Though Miss Quested is not popular with the English, after the Marabar expedition, she becomes the dearest girl of the English women like Mrs. Callendar, Mrs. Lesley, and Mrs. Turton. If no one has ever seen the cry of Collector's wife, she even shades tears for this happening. The club is fuller than before because several parents with their children come in this club to fear "niggers attacked" (188). The situation is that everything is quite reasonable except hearing the drum of Moharram. But all Englishmen are busy analyzing the 
situation knock and corner that English lady cruelly and brutally "crushed her into a cave among his servants" (226). Though they do not point to Fielding's integrity, they think of bribing Godbole to make him late. The Superintendent gives a speech in the trial with a view to showing the audacity that it is "the natural gestures of an inferior race" (225). He is feeling not only hatred towards Dr. Aziz but "merely an abysmal contempt" (225) also. The Police Super always tries to prove his character by showing a woman's photograph, but Fielding makes clear the truth of his wife. The Marabar expedition has a terrible strain which changes the local administrationmany one are in a good position, others in distress. Adela has no affection for India and Indians as human beings because justice does not satisfy Indians, which forces the British to rule them. Even she feels irritated to write an apology letter to Aziz.

In this novel, it is observed that English people prevails a view- Indian natives do not regard anyone after several meetings with him. It is English prejudice that "when an Indian goes bad, he goes not only very bad, but very queer" (177). To Fielding, in India, everything goes wrong. "This city is full of misstatements" (122). Everybody runs towards the rumor. In the Collector's twenty-five years of experience in India, he has never seen "anything but disaster result when English people and Indians attempt to be intimate socially...Intimacy-never, never" (173-174). They hold their occident point of view regarding orient, as Mr. McBryde views on Indians as unfavorable other, not as a human being "all unfortunate natives are criminals at heart, for the simple reason that they live south of latitude 30" (176).

\section{Orient's View and Attitude as Antithesis in a PASSAGE TO INDIA}

Knowing the west's misconception, the people of Chandrapore glorify their place to English people not to treat this place "as meager" (32) but to take the proper documentation of their "disillusionment" (32). Dr. Aziz's encounter with Mrs. Moore in the mosque shapes his helpful sense to Mrs. Moore and Miss Quested. But in a moment, they change their view to show a disappointment of some "Indian etiquette" (85), which inspires them to give "some blunder' (85) and offense. The alarming comment, "India's a muddle" (86) that is smoothed by Aziz's saying, "there'll be no muddle when you come to see me" (86). Aziz's invitation is a chance for Miss Quested to avail the opportunity to know the country through meeting Indian people. Aziz places himself as a right person for English ladies to remove the negative view regarding Indians and shows his positive characteristics like generosity, forgiveness to erase their negative mentality about Indians. Aziz's eloquence in the description of his profession and operation is to prove his broadmindedness to Adela. His main intention is to arouse the remorsefulness of the English for their non-acceptance of Indians.

Aziz becomes irritated for being insulted by the English after the trial. So he decides not to do anything in British Indian, he wants to live in a Muslim state where no English man can insult him. After many happenings during their friendship, Fielding and Aziz do not expect anything more, only for their racial differences. The disaster for the Marabar Caves expedition makes a question at their closeness. Even Aziz considers Fielding as an English propagandist, which prompts his suspicious mind at work. Suleri (1987) upholds that "suspicion in the Oriental is a sort of malignant tumour, a mental malady, that makes him self-conscious and unfriendly suddenly; he trusts and mistrusts at the same time in a way a Westerner cannot comprehend" (267). Dr. Aziz suspects Fielding to go to England to marry Miss Quested to collect money from her, though he does not believe in his suspects "suspicion and belief could in his mind exist side by side" (275).

His suspicion builds a castle of evil dealings. Aziz easily believes the rumor of Fielding's marriage with Miss Quested. For this rumor, he becomes somewhat uneasy, which makes a hindrance in his life to live. With a blind mind, Aziz is determined not to see him at Mau. The news from Fielding's letter for his marriage- "to marry someone whom you know..." (289)- forces him to stop the reading of the message. Without understanding whole things, he lifts to a decision to feel a genuine hatred of the English, though at first, he believes in Fielding's sacrifice for him. But Aziz acknowledges that "I am Indian at last" (290). Dr. Aziz admits an orient's inability to understand people well. Miss Quested's comment on the club's activity as "tennis and ridiculous gossip" (91) makes his surprise for criticizing her community. Aziz does not take it as accurate for his dilemma attitude towards the English people because he thinks that it is her way to "report him for disloyalty" (91) to her community. Aziz feels hesitant to expose all secrets of his thought to Fielding, deciding "I shall not be intimate with this fellow" (129). Another social scar of Indians is the belief in the ghost. "Belief in ghosts ran in his (Dr. Aziz) blood" (42) is a sense of orientalism. Muslim's belief in superstition blocks the advancement of India. The superstitious practice of Indians deters them from coping with Anglo-Indians and enter into their club.

Openly Mahmoud Ali blames the English justice to set aside the truth and hides it from a general human. The white people are too inclined to believe the fact as Hamidullah analyzes it. They are always obsessed with pre-idea or oriental ideas. The occidental social structure in India creates eastern confusion, "the celebrated oriental confusion appeared, at last, to be at an end" (143).

Indians like the East are interpreted and run by the Anglo- Indians without holding their views. Indians 
are in a dilemma to keep their perspective and way of life. They always busy with making themselves a positive entity to the English, removing the scar of negative existence. The English sometimes break the axis of the center of views regarding Indians, but they afterward come to their actual center to recognize the Indians. Anglo-Indians always try to control and show superiority over Indians. Gandhi (2007) unearths:

Orientalism is the first book in a trilogy devoted to an explanation of the historically imbalanced relationship between the world of Islam, the Middle East and the 'Orient' on the one hand, and that of European and American imperialism on the other. (9).

So, Forster, as a twentieth-century novelist with colonial experience, shows his far-cry to marginalize the representations of otherness in colonial fiction. But his treatment of the otherness of the orient makes his position a mystery. He creates an abortive platform to build a bridge between the East and the west in the colonial domain of British India. He tries to transcend all encumbrances of the colonial situation on both colonialists and the natives because he wants to formulate a new set of social interactions and crosscultural bonding.

\section{SYNTHESIS}

\section{a) Discussion on A Passage to India}

Dr. Aziz offers Fielding to look over "an oriental interior" (127) to take his place home by showing "hospitality of the East" (127). Indian knows that English woman is good in England, but India does not suit them. They are so much scared to "entertain regular AngloIndians" (131). The expedition to Marabar Cave is the happiest moment of Aziz's life. It is done for the honor of English guests to make them understand that Indians receive the other country's people as a guest giving remarkable hospitality though "like most Orientals, Aziz overrated hospitality, mistaking it for intimacy, and not seeing that it is tainted with the sense of possession" (154). They think that their "honor was involved in their happiness" (154). Any discomfort of the guest hurts his soul. Adela thinks of Aziz as "a handsome little Oriental" (163). Miss Quested attempts to renounce her community by withdrawing all accusations towards Aziz. She fells herself into the mass Indians' shop-keeping class. But to her, the smell of bazaar is sweeter than London's slum. Fielding has the ingenuity and courage to go against the whole race who wants to meet Miss Quested to ask whether it is "Aziz who followed her into the cave" (179). He is bold enough to declare his innocence to his people as Fielding's concept is to be individual more to "understand other individuals" (133).

Mrs. Moore and Miss Quested have to wait for a carriage arranged by an Indian lady and a gentleman to go to Calcutta, but it does not come, which creates a significant effect on them. Fielding at that time tries to make a bridge over a gulf between Dr. Aziz and them by showing the fact of their "some misunderstanding (85). $\mathrm{He}$ tries to control the situation urging them to remove any wrong idea about India. "No English man understands us except Mr. Fielding"- is Aziz's thinking. India is a place of wonder, to Fielding. To know about India and Indians, they have to live there for about twenty years. Indians always try to create a good impression on the English people doing positive works and being punctual in any meeting. But this kind of situation creates a breath with "mortal air that surrounds Orientals and all men" (75).

The visit of Lieutenant-Governor of the Province gives a decomposition of Marabar. He deplores racial prejudice, who appreciates the outcome of trial and Fielding's sensible side. He makes a pave way to rejoin him in the club. Miss Quested accuses herself and accepts all happenings as a punishment for her stupidity. She gets the worst attitude from both worlds. Whenever it comes to compensation money, Aziz visualizes the death of Mrs. Moore. After struggling with his mind, he decides to renounce the total compensation of funds. When he sees Ralph Moore, he overwhelms with his physical structure because he is an Oriental. Though he complains that "the two nations cannot be friends" (306), he feels to pay homage to Mrs. Moore's son. Aziz only plans on the water for a short half-hour visit at Mau, for his heart is involved with him. Moreover, Fielding's visit to Mau shows a link that is necessary to regain his friendship with Aziz since the free exchange clears up all the misunderstandings between them. Tayeb (2004) narrates that the novel shows genuine encounters between the colonial and the native and some love-hate friendships. He also says that "the colonial bridge is predicated on the assumption that the English and the Indians can criss-cross the enchanting path of friendship so long as they can ignore the cultural difference and colonial grudge."

As an English writer, the writer clarifies the trueness of this concept forcefully and tries to reconcile the tension of orient and occident. But, in the plot development, it is observed that conflict may arise within a race, but mutual understanding can be a bridge of the conflict. Moreover, humanity wins over all the disputes and proper understanding can synthesize the crises between the orient and the occident, especially between Fielding and Dr. Aziz. Fielding is a true friend of Aziz to understand his incapability of thought in Aziz's misery though Aziz feels bitter. Fielding denies his concern, "how is England justified in holding India?" (124) because "it's beyond" (124) him to understand as a part of a human being in the globe, and it is politics that he does not care. Fielding holding fellowship and unanimity among the member of a superior race preserves a façade of cheerfulness and gives the value of a man as this novel is the portrayal of varieties of human behavior by acknowledging social differences. 


\section{b) Discussion on A Passage to England}

The accepted view-the West and the East will never be in harmony- is practiced in the world when the orient and the occident are analyzed. Belonging preconceived views, the writer feels doubt to meet occidentals in India. At the age of fifty, he sees the deterioration of Hindu traditionalism from his contemporaries. The view of the west confirms his doubt by certainty. The writer's body and spirit find comfort in Italy and all Western countries. When he visits Kent, he views the removal of wildness from England, which is felt in the tropical East.

The clash of beliefs prevails between the East and the West in Chaudhuri's travelogue. The writer observes that England even loses its interest in the outside world. Losing their empire in the world is a significant gain. The ordinary people do not understand their empire. The writer exposes a truth that "the dying empires are kicked, living ones never" (94). The writer's previous knowledge about town taken from Cowper's thinking, "God made the country and man made the town" (38), is halted when he sees London town. He is bewildered by a song of thrush and blackbird in this town. The west prevails their preconceived idea that the Hindus consider the world as an illusion, but the writer rejects this view as a misconception that the Hindus believe to be born in this world again and again. The world is eternal for them, so they do not dismiss the world as insubstantial treating it as property. But it is true to the west because their religion teaches them to believe in the intellectual world. They want to live in that world eternally after demolishing the material world. The Hindu, that's why rejects comfort and the Western attempt of improving the standard of individual lifestyle. They want to inherit much wealth and make sure of everyone's inheritance of wealth. Thus, they will create a welfare nation after their rebirth. With the map knowledge, the writer thinks of the world as a phantom. But the reality is bewildering when he lands in England for this dissimilarity with his reading, the play scene, and the existence of the English stage. The real England shatters his dream by experience. The writer's previous theme of Western music rests in his eyes when he observes the Thames where the river and the city become connected. "The oppressive sensation" (62) is felt from the houses and the life in these parts.

The large-heartedness breaks the distinction between public and private life in India, which is an attempt to remove misconceptions regarding the East. As a detached observer and as a traveller, Chaudhuri talks of his experiences with human beings. There is no pondering over a particular person and dissection of Indian traits. It is authentic, accurate, and devoid of emotion. The writer makes a unique statement by way of comparison. He puts forward the Hindu conception of an evolved human being to make a challenge to the prejudices of the English:
Those Occidentals who call us economically backward, or euphemistically 'under-developed' in pride of technological progress, have no inkling that in another aspect of economic life they are far less developed than we Hindus, who look upon the millionaire as the natural complement of the Sadhu. (124)

The sympathy showed by the Indians makes them "recoil from the dreariness of the public behavior of the English people" (86). All things that Indians know about the English through reading books are absent in an English man. But we know about our country ourselves and Hinduism from the books written by an English man. Since the East cannot define itself, the East relies on the western definition of the East. The west wants to imbibe the concept of English life in the Indians through literature. But this kind of reading does not succeed in its purpose. The writer places a view that "every nation has its peculiar manner of self-projection" (95), and since climate controls our capacity, it is foolish to talk. Only we can express a particular part of an English man. Moreover, he posits an opposite view that the East and the West will never meet not because of Anglo-Saxon pride or Hindu xenophobia, but because of temperature. It is nature that separates the two cultures. In England, the author observes a close relationship between man and nature; "...man and nature have got together to create something in common" (33). The traveller Chaudhuri becomes aware of the cause of the Englishman's outrageous colonial behaviour after observing the English weather. The hot weather makes them offensive, devoid of their "kindliness and equability in human relations" (99). The writer disagrees with the orientalists. He has labeled the natives and has considered the tropics as effeminate and barbaric. From an occidental's point of view, it would be wrong. They become "raw and crude" (99). According to Chaudhuri, "...they degenerated into outright cads, and the more sensitive or specialized the English organism, the more warped it became" (99). Chaudhuri skillfully uses terms used by orientalists to interpret the way the British behave with the orient. The travelogue exposes the English milieu, its roots, the societal norms as an epitome of cosmopolitan culture, ignoring the author's childhood idea of the 'white' rulers. Avoiding the misconceptions and the prejudices that control the Indian mindset, he discusses an almost favourable image of England and her eminent people.

But we consider their books, their knowledge, and their learning positively, "even in regard to Hinduism most Hindus prefer to go by an English book" (92). The conflict between the fascination for the west and the assertion of the orient's distinctiveness is dexterously disguised under the humanity sense. In the same way, Chaudhuri, in his travelogue, through his perceived understanding of English and western culture from reading books, places superiority of English over Indians to remove the conflict. Simultaneously, the writer 
upholds some positive and generous attitudes of Indians to remove the prevailing views on the orient. Moreover, the writer places some limitations on the lifestyle of the English to put the orient in a positive sense. Overall, the writer intends to show each nation's individuality possessing different characteristics. Chaudhuri, in his travelogue turns the occident's view on the orient as a negative other to the orient's view on the occident as positive and inspiring others. Thus, he makes an easing condition in the conflicts of 'Orientalism'.

\section{Conclusion}

By comparing these two books, it is observed that since it is beyond understandable of human characteristics to move from conflict to harmony, the power of reason becomes limited for grasping and expressing any kind of truth. It is the fact that conflicts between the orient and the occident create a hindrance to mix the two races in the novel A Passage to India. But Fielding and Dr. Aziz's relation, Aziz and Mrs. Moore's family, clarify that the actual feeling from the heart can remove all kinds of conflict. They can create a harmonious situation even between two different races as a real sense of humanity can cross all hindrances to assure a peaceful co-existence among human beings. Besides this, a positive outlook regarding other nations can erase one nation's limitation and can ensure harmony between two countries, as reflected in Chaudhuri's travelogue. Thus, the conflicts in orientalism find a comfortable explanation in these books.

\section{RÉFÉRENCES}

1. Barry, Peter (2006). Beginning Theory. T.R. Publications Pvt. Ltd: India.

2. Bertens, Hans (2001). Literary Theory: The Basics. London: Routledge.

3. Gandhi, Leela (1999). Post-Colonial Theory: A Critical Introduction. A Review of International English Literature, 99(4).

4. Goodman, W.R. (2004): Contemporary Literary Theory. Delhi: Doaba Publications, p.p. 89.

5. Lowe, Lisa (1991). Orientalism as Literary Criticism: The Reception of E. M. Forster's Passage to India. Critical Terrains Book Subtitle: French and British Orientalisms. [Online]. Available at: https://www. jstor.org/stable/10.7591/j.ctt207g5rk.7

6. Nayar, Pramod K. (2010). Contemporary Literary and Cultural Theory; From Structualism to Ecocriticism. India: Dorling Kindersley, p.p 161.

7. Suleri, Sara (1987). The Geography of A Passage to India. Bloom, Harold, ed., E. M. Forster: Modern Critical Views. New York: Chelsea, pp.169-75.

8. Tayeb, Lamia (2004). The Inscription of Cultural Bafflement in E. M. Forster's A Passage to India. Interdisciplinary Literary Studies, 6(1), pp. 37-59. 